\title{
The Family Struggle for Independence in Gita Mehta's Raj a Historical Perspective
}

\author{
Dr. R. Anne Margaret \\ Senior Lecturer in English (Asso Professor in English) \\ ABM Degree College, Ongole, Prakasam DT, A.P. INDIA
}

\begin{abstract}
The exploration paves the way for unraveling the entanglements involved in the freedom of women. It shows how Virmati, the narrator's mother toiled hard to realize even the very feeling of liberation against all the obnoxious patriarchal conventions of the society. Virmati as the eldest of eleven children, witnesses the harassment of her mother in every aspect of life. Inspired by her grandfather's championing of the cause of education for women, she nurtures the aspiration of breaking patriarchal conventions in the society. Engaged to Indrajit, she becomes an intellectual companion to Prof. Harish Chandra. Her attempts to acquire self affirmation are torn in between love, duty and desire for education. She finds liberation and solace in education rather than an in initiation into womanhood. Realizing that her relationship with the Prof. of English becomes an emotional entanglement she gives up the relationship. Virmati's realization of freedom is juxtaposed with the National struggle for Independence. It is during the circumstances of partition and communal riots Virmati achieves her world of freedom. Contrary to this, Gita Mehta's Rajexplores the freedom of woman born in Indian nobility during the pre Independent times. The protagonist Jaya Singh is brought up under tradition but educated on modern lines by her father on par with her brother. Understanding defiant nature of her father in paying submissiveness to British, she develops a strong individuality of her own. Jai singh with the fear of losing his son trains Jaya as a ruler. Jaya Singh learns the maneuverability in ruling and the principles of Rajanit from Sati Mata, Lord Modi and James Osborne. At the same time, she disallows Arun Roy and James Osborne to exploit her. But indulges in intrigues with Arun Roy and gets labeled as a traitor. Fearing the future of her kingdom, She accounts herself with all the dignity and deconstructs the patriarchal authority.
\end{abstract}

Keywords: Historical dimension, independent liberation, submissiveness, individuality.

\section{INTRODUCTION}

Gita Mehta's Raj is a thorough and colorful historical story that follows the progression of a young woman born into Indian Nobility under the British Raj. Through Young Jaya Singh's story Mehta's readers are shown a portion of the passage of British India's early struggle for Independence as it has affected a small segment of high culture in Indian society. Through her story Mehta not only weaves together elegant language and colorful pictures of Indian culture, but also paints a picture of Indian colonial life from an Indian perspective. She presents historical facts with gentle persuasion in a beautifully oven tapestry based upon her female protagonists strength of character.

In an Interview with C.J.S. Wallia Mehta says: "The problem with Raj was that I was being bent all the time to a kind of fictional American shop girl reader. I think Simon and Schuster's idea was that I would write this blockbusters, which I am not capable of doing - I am not enough to do it" (2).

At centre of this epic novel is Jaya Singh, the only daughter of the Maharajah and Maharani of Balmer. She was raised in thousand year old tradition of purdah by her mother and was educated like her royal brother Tikka, according to her father's decision. Jaya has fair eyes and dark skin of her father. The rulers of India are preparing for the Diamond Jubilee Celebrations of Empress Victoria's accession to the throne of England. The Maharaja of Balmer has played host to various European monarchs and is among the favourite and superior most Indian rulers in the eyes of the British but his actual condition is no better than that of a puppet in their hands. In spite of being a far sighted, considerate ruler who is respected by his subjects he is forced to indulge in clandestine negotiations with the Russian Tsar when his state is under financial stress due to the famine. He goes to England not to pay his homage to the Victorian empress but to negotiate with the diplomats only to save himself and his kingdom from further humiliation. 


\section{Dr. R. Anne Margaret}

Jai Singh is reluctant to obey all that the British want him to do, but he is gradually reduced to a complacent king by the encroachment of the British power. He does not want his son to acquire an education in England which will teach him to look down upon his own country. Tikka is persuaded into thinking that unless he too adopts the life style of the Princess of Sirpur and other royalty he will not be able to bring honor to Balmer.

Maharaj Jai Singh is unhappy in sending his son to England and to deploy his forces under the command of Tikka to participate in the world war along with the allied forces. But he is rendered helpless by the fear that his secret negotiations with the Russians may be discovered and he may be punished for treachery. Jaya's education which is comprehensive is at once traditional and modern. She learns riding, hunting and shooting to confront her fears. Her father taught her the philosophy of monarchy. According to her father: "Rulers are men and men are always frightened. A man cannot govern unless he confronts his own fear"(5). Her teacher on the field is Major Vir Singh who is indifferent to the fact that she is a girl. Another teacher is the Raj Guru who gives her lessons in Rajniti and to whom she turns for advice later on. Her mother on the other hand fears that her father is bringing her up as a son, and seen to it that she is taught the sole stringent, the traditional art of personal decoration, music and also the aesthetics of color and design in order to please her husband. Another Major influence on her is of Miss Roy who teaches her English literature who also passes on her nationalistic ideas to her. Tilak's "Freedom is my birth right" has become a personal slogan to her.

Jaya as a child discusses the under currents of tension in her father's mind. She understands his silent hostility towards the manner in which the British, who are superficially the benefactors and wellwishers of the natives, are actually exploiting them: "Jaya knew her father was not content" (88). His fear that he may lose his son in the war prompts him to train his daughter as a ruler. He is fully aware of the subordination he has been forced to adapt to and when Tikka insists on heading the Balmer forces he states "what honor is there in strengthening those who have made us a subject people, forced to plead for what is ours? I am accepting an intolerable blackmail to consolidate your rightful position as heir to the Balmergaddi" (113).

The Rajput honor which cannot tolerate the label of cowardice makes him sacrifice his son in the "battle of the foreigner's". As he explains to his troops before their departure: "I say to these Angrez officers who draw their wages from war, by what right do they call Udaipur a coward? Let them call up the Ghosts of a thousand kings who have died in battle; ten thousand queens who have burned themselves for honor before they dare speak the world coward to the scion of Chittore and the line of RanaPratap ... It will never be said that BalmerLaucers fought for payment. We are Kshatriya's the warrior caste. We fight for Dharma" (116).

But this heroic Kshatriya is shattered by the death of his son. His efforts to keep the English at bay from the affairs of his state end in vain and the conspiracy of Raja Man Singh, who is a sycophant of the foreigners, result in the installation of his son John as the next ruler of Balmer. Having fought a losing battle the Maharaja ultimately succumbs to the pressures that have exhausted him and dies. The situation is not any happier in the family Jaya marries into. Maharaja Victor and Prince Pratap, her husband are eager to please the British with a lesser degree of dignity like Raja Man Singh and others who were even ready to prostrate before the foreign masters. Jaya is once told by Prince Pratap "Living without pride is not a pleasant business" (265). This one sentence summarizes the plight of the Sirpur Prince who is supposed to be the descendent of the oldest ruling family in India.

Jaya and Pratap's marriage is an ideal alliance between two leading aristocratic families and a financial bargain that has placed the Sirpur House under the favor of Balmer. Jaya's dowry helps sustain as well as fan the whims of Prince Pratap. He once requests for an advance installment of the annual payment made to him by Balmer only to be able to join the festivity in London, at the coronation of Emperor George. This is to remain in the good looks of the complexity of Pratap's relationship with the empire. This is reflected in these lines: “. . . . The more Maharajah Pratap prostrated himself before the British Empire, the more he hated his wife as the symbol of that empire's power over his private life" (288).

Jaya recorded all events of her life in an album. She was weighed with Silver in Kings presence. Jaya was unhappy with the comments of voluptuous women of the palace about her unencounterd husband. She married off to Pratap in-absentia. It is almost two years before he returns from abroad and meets 
her and another five years before their marriage is consummated. And when she appears in her traditional bridal finery, he rejects her saying: "I am afraid you won't do princess. You really won't do at all" (189). He wanted her to "wash all that nonsense off your hands and feet. And change out of these Christian decorations" (189). In the second meeting he makes his motives clear. With chilling bluntness he tells her that theirs was a marriage of convenience and adds: "Should the necessity for children ever arise, I am sure we can both rise to our duty, but until then . . . . (190). The British consider him to be an "irresponsible play boy" who would be permitted to travel abroad only when accompanied by a wife "That's why I greed to our marriage. You cannot eat quail or wear a sari. You know no languages. Yet through you I must outmaneuver the empire which forced me into this marriage" (191). He appointed a lady to teach her intricacies of western society.

The lessons taught to Jaya by Sati Mata leave an impression on her mind: "Go towards your fear child, only then you find the courage to endure the life that stretches before you, exiled from sex ... few will understand the high cost of your valor, child, the impoverishment of your spirit. But you must find the courage to live with your bareness" (126). The bareness referred to here is symbolic of the futile endeavors of a woman to assume a central role in a world where she is deprived of love. Jaya is destined to enjoy fame and popularity in the royal circles but her life remains barren because she is never loved by her husband. Sati Mata also explains that a true Sati is not one who ends her life on her husbands funeral pyre but one who is virtuous: "And the greatest virtue is endurance. I am called the Sati Mata because my gurus are the five Sati's, those five virtuous women who refused to burn themselves on their husband's pyres. The true Sati has the will to continue when the familiar world fragments around her" (27).

Lady Modi enters Jaya's life. She says that Jaya is hairy and Pratap didn't like it. He wants her to be fashionable. She too should wear Sari, hand gloves and handbag like Maharani Cooch Behal. Under lady Modi's tutelage she lost her self-consciousness. Pratap felt happy when he saw Jaya with her hand bag, high heels and unpainted hands. He kissed the hands of Lady Modi congratulating her but not Jaya. Jaya feels capable of conquering, her husband through her endurance and never demands attention or intervenes in his affairs with other women. Once during all emotional moment of remembrance when Pratap is recounting the experiences of war to her, he remarks: "But for many of US, including Tikka it was the only time in our lives when we were permitted to be men. Living without pride is not a pleasant business, princess". Jaya quietly replies: "An unwanted wife shares the experience, hukum" (265). This single sentence is perhaps more pregnant with meaning than any long speech that she could have made. When finally their marriage is consummated by Prince Pratap, it is with an "intimacy which soiled her as his remoteness had never done" (287). The experience is described as an uncleaning memory and the irony of her situation that the long wait for love had now turned into a compulsory acceptance of him to provide Sirpur with an heir. She withdraws to the Purdah Palace immediately after her conception.

She tries to find fulfillment in maternity and is upset when Maharajah Pratap compares her with a peasant women when she is feeding her child. She secretly resents his disapproval of her act and his suggestion that a wet nurse be employed for her child because she feels: "Maharajah Pratap had already robbed her of the dignity of being a wife. Now he was stealing the rights of maternity. She lowered her eyes so that he would not see the silent anger breaking in waves against the respect for a husband which had been ingrained so deeply by the prayers and ceremonies that had marked her whole life" (298).

But, though she endures a good deal, Jaya never gives up; she fights for her rights and proves to be a hard bargainer. However, Jay with in the given tradition makes a place for herself within it and then empowers herself. Jaya is a strong woman and though she goes to great lengths to win over her husband she has a mind of her own. For instance, she summarily rejects the advice of Lady Modi who has been employed to teach her the intricacies of the polite society, to have her hair cut, saying: "Long hair is one of the emblems of a married woman. I will not cut if off. It would be inauspicious for my husband (195). Later she refuses to wear a glove and greets the Prince of Wales with folded hands. In an atmosphere where everyone is mindlessly fashionable and trendy, there is a positive merit in being traditional.

On two occasions she actually strikes a hand bargain with her husband who wants to create the right impression on his imperial masters. First, she agrees to play polo with the visiting prince of Emperor himself: to put his arm around her body" (202). Her 'goal' as the Prince of Wales said later, 'was the 


\section{Dr. R. Anne Margaret}

best goal in the game' (225). The polo marks a great accession to her strength. She is ashamed of her husband's sexual exploits and particularly about his aping his British Masters by choosing to wear the Sirpur Crest not on his turban but on his slippers, which one of his concubines returns with respect to Jaya.

Jaya's diplomacy and capacity to mediate make Pratap strike a bargain with her that she would be the Regent of Sirpur in case of any untoward happening, until their child grew up, in return for her help in getting rid of his Anglo-Indian mistress Esme Moore. His intimacy with Esme is disliked by the British and his chances of assuming the throne are threatened by their relationship. Jaya efficiently manages to handle the issue and is surprised at her husband's perception of her desire to be in power: "Your price would have to be power", he tells her and Mehta writes, "After a life time as power's victim she wanted to be its executor" (333).

Jaya is fearful for the future of her kingdom. "When the strongest kings in India were important before the might of the British Empire and the ambitious of the Reformists, how would she hold a kingdom for her son if anything happened to her husband? (338). Like her father, husband and brother, Jaya has to compromise with the British. Her son is sent to a school in England after being tutored by an English teacher at Sirpur for a while. She has to keep doing a number of things against her will to keep her Sirpur seat intact. She also has to depend on the calm composure of James Osborne whom she has known since childhood and Sir Akbar, the Prime Minister of Sirpur, to keep herself going. Unlike her male counter parts she does not allow any body to get the better of her. Undaunted by the death of her husband, and later of her son she continues to administer her state with the help of James Osborne and the advice given to her by Vir Singh and the Raj Guru of Balmer recollecting the lessons and Principles of Rajniti taught to her as a child.

She too indulges in intrigue with the nationalists and Arun Rohich she is labeled as a traitor in the secret files of Osborne but she can easily manipulate the situation when she realizes that Roy too has intentions of betraying her. She changes sides immediately and is redeemed in the eyes of the British who commend the maintenance of law and order in her kingdom during the communal riots before and after the partition. Jaya does not allow either James Osborne, Arun Roy, the two men who have symbolized or even given her the tender love denied to her by her husband, to exploit her except momentarily. As progressive thinker, Jaya does a great deal to improve the kingdom of Sirpur. As Regent, she accomplishes many tasks of public welfare. However, she becomes a victim at the hands of Arun Roy. He comes to her kingdom and tries to alienate her own people from her. This is symbolic of the fact that the political game is dirty whether it is played by the British who are exploiting the colonies under the garb of being well-wishers or the nationalists who are pretending to be the friends of the native Indian rulers and are actually turning their subjects against them. When Jaya accuses Arun Roy of betraying her trust: "To take me in your arms, knowing you would use your power to discredit my son's throne and destroy all the work that I have done! (418). "Roy's response is not at all apologetic: 'Roy caught her hand, and the smile no longer reached his eyes. No bargain was struck between us, Bai-sa: You came to me of your own free will. Did you think your beauty would prevent me from telling your subjects the truth? (418). As suggested earlier, the novelist presents Jaya as a true Sati. She does not consider her seeking sexual fulfillment in the arms of Arun Roy inconsistent with being virtuous. If she sleeps with him she does so with dignity and does not abuse herself. The event is significant because its shows that Jaya is not ascetic and because it brings her the long denied sexual fulfillment and also because it wipes away the humiliation she has suffered at the hands of her husband. It is also an earnest of her expanding consciousness because she defies conventional morality and notions of purity. Even though, Jaya is dependent on male advice and guidance she shows a tendency to be able to take her own decisions which are generally correct and it is only with the approval of the men she respects that she carries on with her plans. Her father had been far sighted enough to leave some economic resources in Tiny Dungra's custody for her and Jaya utilizes these when she feels the need to secure the Sirpur seat for her son, by spending money on providing the kingdom with modern amenities. She evades any controversy with the Sirpur priests after her husband's death and shoulders all her responsibilities efficiently. In fact she does not allow anybody to get the better of her till the end when she leaves Arun Roy and Osborne absolutely nonplugged by filing an election petitions to contest in the forth coming elections. She is amused at their argument whether the British of the Indians are the initiators of the democratic process in the Indian Kingdoms. She realizes that they are both in capable of deciding the issue because the people will do so by electing the ruler who looks after their interests. She recalls the Rajguru's question when she 
had gone to him for guidance what is the first principle of Rajniti, Bai-sa? and her stuttering reply, 'The people'. The book ends with her mocking laughter which also symbolizes her triumph. Jaya's visit of Sirpur and its jungles along with Arun Roy signifies her defying of conventional morality. And her relationship with James Osborne to whom she was attracted even as a child verges on an intimacy which remains unspoken because he is too conventional and perhaps too British to indulge in an affair with an Indian princess. Naresh K. Jain explains her brief interlude of love with Arun Roy as an "expanding of her consciousness". Mary Eagleton points out that stigma is generally attached to the expression of sexual desire by woman. Jaya seems to be making an effort to deconstruct patriarchal authority. Her vulnerability to James and Arun Roy's gestures of love is a result of the repression and humiliation she suffers. Her response to them is a form of defiance of her husband's power over her. It is because she has transcended the limitations of her sex she is able to emerge victorious over the other repressive forces in the world. As Regent, Jaya is left alone but she conducts herself with dignity and restraint and gives a good account of herself as a ruler. As the nationalist movement gathers force in British India, she naturally feels anxious about saving the kingdom for her son. She is in a dilemma and she learns upon her childhood friend James Osborne who is now political officer to Sirpur for advice but at the same time she tries to cultivate the nationalist leader Arun Roy. Since she is clear sighted and her democratic instincts sound right at the Right time. Mehta is able to offer a complete story without bias or bitterness and, like in her other books, leaves the reader to formulate an independent position from which to read the history she tells. Lelia in her review: "Thoroughly enjoyed" says that Raj is "A historical novel with a wealth of detail, capturing the flavour of life during a pivotal time in India's history. It's key moments are women into the story, with careful attention given to the impact on the people and the feelings each event generated. This novel stays well away from the common pit fall of historical novels, that of applying modern morals and ethics to history. This story has an authentic ring through out. A wonderful introduction to the impact of the British rule and Independence on the Indian life at all levels. It is a novel, not a detailed historical treatise, but it does an excellent job of high lighting areas that might be interesting for future research" (March 5, 2006). Alexandre in his opinion on Raj, in the essay "Read well while travelling in India" says that, "I read this while travelling in India. Being in the country truly brought the book alive as I felt it helped me to not only understand what I was seeing in this vast country of such an extra ordinary culture but to 'feel' as if I was transported to that time" (February 24, 2006). While her intelligence is obvious and her opinions clear, she is ultimately not interested in pressing her political impressions onto her reader, but presents historical facts with gentle persuasion in a beautifully oven tapestry based upon her female protagonists strength of character. Amir the Shahazad Khan of Pakistan in essay "The Best Novel I ever read by an Indian" says that, "Raj is simply the best novel I have ever read by an Indian writer. Gita is successful in portraying her intellectual, historical, emotional, and fantastical abilities" (Sep 13, 2005). Another reviewer AppiAppi of India in her review "Love in the Times of Colonial Rule" says: "Raj is an immature attempt at weaving a historical saga with the back drop of British rule and the Indian royal families. The prose is very average, at times worse than the average romance paperbacks. Jaya Devi the heroine is completely unidimensional who suffers sacrifices and succeeds" (April 14, 2005).

ElizebethM.Bolie in her review "A Treat of a Read", says: "Gita Mehta has written an eye opening novel that exudes the sights, sounds and flavors of British - occupied Indian from the perspective of a prominent native. Few novelists and no women, as far as I know - attempted to piece together that dark of piece of history as well as this talented author has. For those who are interested in rediscovering the flight of India during this turbulent time, this is the book to read" (Feb. 16, 2005).

Jana L. Perskie, Ceruleana of New York in her review "British India and Royal India under the Raj" Says: "Author Gita Mehta demonstrates her extraordinary grasp of the historical, political and cultural complexities of India, British and royal, under the Raj. She writes with realistic details and subtly about the period from queen Victoria's Diamond Jubilee to the violent bloody civil wars for independence (Dec. 14, 2003).

W. Montegomery of Washington D.C., U.S.A. in his review "India and a princess in evolution" he says: "This money reads as a chronicle, not only of princess Jaya's life hit also of an India for nation from the late 1800s up thorough the early years following independence in 1947" (July 7, 2003). Aliya of Los Angels, USA in her review "Perspective of an Indian Princes", she says: "Even though the novel was generally wonderful the characters were not as sprightly as the images. There was not much character development than one could reflect upon as the end of the story. Even though the 
characters were a fit blend the style more than made up for it. A reader could feel the genuine and original knowledge of the subject with a strong news of Indian culture" (Jan. 11, 2004).

AlokChakrabarti of Berkely, USA in his review observes: "A panoramic view of the British India from the perspective of a wealthy woman. Mehta has provided a sympathetic narration about the life of the native Princess and their family life under the watchful eyes of the British. She also portrays the decadence that brought to this Anglican culture developed in India" (April 30, 2004). Naresh K. Jain in his review "From Purdah to polo to politics: A study of Gita Mehta's Raj, he says: "In Jaya Gita Mehta attempting to present her ideal of an androgynous woman combining devotion, affection, and endurance with fearlessness, coverage and ambitions" (213).

Jaya is truly janus faced looking back to the past and looking forward to the future. She is a battle scanned woman who does not remain locked in the memories of past glory but is ready to seek new pastures in the fiercely competitive world of national politics. Two symbols recur frequently throughout the book: the machine and the bracelet. Glass bangles or glittering gauntlets are forever clinging on Jaya's wrists like manacles, are the symbols of her young servitude to tradition. Dressed by servants for her marriage to a man she has never even met, she felt "suffocated as the women scratched her body with jeweled gauntlets and heavy anklets" (170). But when the young Englishman she had loved dances with her at a ball, her bangles break in his white glove. The machine is introduced as a destructive force, often in conjunction with money.

\section{Conclusion}

Thus we learn early on how drought turns Jaya's ancestral country into a wasteland of exploitation. It is the palace guru who believes that by adopting the machines and institutions of the British we would adopt their ways, and in the process lose our souls. Jaya's father is shocked by the idea of investing money in stocks, for money lending is undignified; it is against the dharma of a Rajput warrior: "Dungra's thick lips, stained red with betel juice, opened in laughter, 'Dignity? Dharma? You live in the past, Jai. Such words have lost their currency. Now the world runs on money" (22). The old world of customs and warriors against the new world of machines and moneylenders; no wonder at least one maharajah is said to have had portraits of Hitler in his study. He was not to know that Hitler, despite his love for Aryan nobility, was hardly interested in saving the Indian soul. Jaya's attitude toward the machine age is one of sad resignation. She thought of her father's mustache falling like a broken wing onto his white tunic as he told the Balmer Raj Guru that machines had ended the dharma of the warrior and with it the dharma of the king. For much of her life, inevitably for an Indian woman in the first half of this century, her destiny is controlled by men. They all represent something: her father, the old world Rajput; her husband, the confused, self hating Anglicized playboy; her Indian lover, the Bengali babunation list; her English friend, the liberal who loves India. These are well-known types, but, as with Jaya, it is their ambivalence that saves them from being cardboard cutouts. For her father may be an old world Rjaput, but he also tries to be modern, forcing his wife to break purdah and help the starving villagers during a famine.

Osborne, the English friend, may be a liberal who loves India, but he remains loyal to his viceroy, to the point of spying on Jaya's activities when he decides they are against British interests. And the Bengali Babu, Arun Roy, is strongly drawn toward the very woman whose power he must destroy. Sex is of course one of the most fascinating aspects of colonial society, the way sex became mixed up with politics. The early British settlers in India, soldiers and traders, employed by the East India Company, had no qualms about taking Indian mistresses: this was one of the "perks" of living in the tropics. But after the British began to rule India, not as traders but as a kind of superior caste, sex with the natives became a taboo, something that upper-caste Hindus understood very well. The taboo was no doubt broken on some occasions, but this degraded the white sahib in Indian as well as British eyes. So even though every encounter between Jaya and Osborne is charged with erotic attraction, nothing happens, nothing can be allowed to happen. Even sex between the sahibs and memsahibs had to be discreet to maintain face in the eyes of the more fastidious natives. NiradChaudhuri, for one, was shocked by the sight of white couples carousing on Indian beaches, thereby "bringing disgrace upon the great European tradition of adultery established by all the historic adulteresses from Cleopatra to Madame de Stael" [2]. The penchant among Indian aristocrats for seducing as many white women as they could was degrading in a different way. But it was also a kind of racial revenge, though the revenge was not as sweet as it should have been, for it was infused with self-hatred. Mehta catches this well in her description of Jaya as a new bride, still very much the traditional Rajput 
princess, pining for her absent husband. This still rings true today. From Bombay to Tokyo, where some women continue to have their eyes fixed to look more Western. Of course this is not for the benefit of Western males, who, in any case tend to prefer exotic Asian beauty, but to suit their own notion that physically the West is best. Jaya tries her best to dress like a European flapper, but never becomes the caricature that her cocktail-swilling friend Bapsy is. Nor does she become quite like Bapsy's opposite, Jaya's teacher, Mrs. Roy, a nationalist from Calcutta, dressed in white cotton saris; earnest where Bapsy is frivolous, loyal where Bapsy is fickle, intellectual and shallow. Jaya never becomes like Mrs. Roy. She wanted to be a dutiful wife, but, rejected by her husband, she ends up hating him and everything he stands for. Gita Mehta is at her best when describing the twisted human relations in a colonial society.

\section{REFERENCES}

[1] Mehta, Gita. Raj. New Delhi: Penguin, 1989.

[2] Rustomji, Roshni Kerns. Expatriation, Immigrants and Literature: Three South Asian Home Writers, The Massachusetts Review, Winter, 1988-89.

[3] Sahgal, Nayantara. "Passion for India." Indian Literature. Vol. XXXII, No.1, Jan-Feb. 1989.

[4] Said, Edward. Culture and Imperialism. New York: Alfred S. Knopf, 1993.

[5] Orientalism. New York: Vintage Books, 1994.

[6] Sales, Dora, Salvador and Rollason Christopher. "Critical Commentaryon ManjuKapur." The Atlantic Literary Review. 4.4 Oct-Dec.2003, 219-48.

[7] Sangari, Kumakum and Sudeshvaid ed. Recasting Women: Essays in Colonial History. Kali for women, 1989.

[8] Sharma, B.D., Sharma S.K. "The Contribution of the Women to the Development of the Indian English Novel.” Contemporary Indian English Novel. ed. New Delhi: Anamika, 2001.

[9] Showalter, Elaine. A Literature of Their Own: British Women Writers from Bronte to Lessing. Princeton: Princeton University Press, 1977.

[10] The Female Malady: Women, Madness and English Culture 1830-1980. New York: Virago, 1987. 